\title{
Preliminary Study of Moulded Laminated Veneer Oil Palm (MLVOP)
}

\author{
Abdul Hamid Saleh (Corresponding author), Izran Kamal \& Noor Azrieda Abdul Rashid \\ Forest Research Institute Malaysia (FRIM) \\ 52109, Kepong, Malaysia \\ Tel: 60-3-62797382Ｅ-mail: hamid@frim.gov.my
}

\author{
Abdul Khalil,H.P.S. \\ Bioresource, Paper and Coating Technology, School of Industrial Technology \\ Universiti Sains Malaysia (USM), 11800, Pulau Pinang \\ E-mail: akhalil@usm.my
}

\begin{abstract}
Ahmad Shakri bin Mat Seman
Department of Civil Engineering Technology, Faculty of Civil and Environmental Engineering Universiti Tun Hussein Onn Malaysia (UTHM), 86400, Parit Raja, Batu Pahat, Johor

Tel: 60-7-453-7311 E-mail: shakri@uthm.edu.my
\end{abstract}

\author{
Siti Zalifah Mahmud \\ Faculty of Applied Science, Universiti Teknologi Mara (UiTM) \\ 26400, Bandar Tun Abdul Razak, Jengka, Pahang Darul Makmur, Malaysia \\ Tel: 60-9-460-2000 E-mail: ifah@pahang.uitm.edu.my
}

Received: April 25, 2011

Accepted: June 20, 2011

doi:10.5539/mas.v5n4p11

\begin{abstract}
This research was undertaken to study the suitability of oil palm trunk to be utilized as a raw material for moulded laminated veneer oil palm (MLVOP). The trunks were converted into veneers by rotary peeling machine. The veneers were segregated into two veneer qualities namely superior (S) and inferior (I). The methods of segregating veneers quality were defined. The superior veneers were obtained by peeling the billets until their diameters left approximately 12 inches, meanwhile the inferior veneers were obtained by further peeling the same billets used for obtaining superior veneers until their diameters left 4 inches. The mean densities for superior veneer as well as inferior veneer were about $478.8 \mathrm{~kg} / \mathrm{m}^{3}$ and $385.1 \mathrm{~kg} / \mathrm{m}^{3}$ respectively. The mean moisture content of both superior and inferior veneers was approximately $11 \%$. The veneers were arranged with 5 layers into three types of moulded shapes of furniture components namely i) $100 \% \mathrm{~S}$ ii) alternate $\mathrm{S}$ and I and iii) surface $\mathrm{S} \&$ core I. The suitable pressure, temperature and time were set as important parameters. The arrangements of veneer quality were pressed using V-shape mould through hot press machine with three parameters pressure $1500 \mathrm{psi}, 2000 \mathrm{psi}$ and $2500 \mathrm{psi}$. Two types of adhesives namely UF and PF were used to produce MLVOP. The mechanical properties of the composites were tested with three bending types i.e. flat bending, type-V bending, and type-OV in accordance with BS EN 310:1993. The results showed that most of the samples bonded with UF-resin have better strengths (MOR and MOE) when tested with the three bending tests compared to the samples bonded with PF-resin. However, the results vary depends on the veneer arrangements.

Keywords: Oil palm veneer, MLVOP, Mechanical strength, Superior (S) veneer, Inferior (I) veneer

\section{Introduction}

Wood-based industry is one of the main contributors that enhance the economic growth for Malaysia. Total export from the wood-based industry is always increasing due to the demand from the global market. In the year 2004 , the demand increased by $24.5 \%$ which was equivalent to RM 14.1 billion. The export of furniture was also increased by $7.3 \%$ to RM 5.4 billion in the same year (Anon 2005a). However, the shortage of raw material especially rubberwood is expected to affect the export in the next few years. The Malaysian Furniture Entrepreneurs Association (MFEA) raised this issue by urging the Malaysian government to provide allocation on Research and Development work towards finding alternative raw materials as a solution to this issue (Anon 2005b). Oil palm (Elaeis guineensis Jacq.) was discovered as one of the potential raw materials to substitute rubberwood for furniture industry. Oil palm was introduced to Malaysia in the early 1900's. Numbers of studies were conducted to enhance the potential of oil palm trunk (OPT) for the production of value-added products by
\end{abstract}


investigating and improving the physical and mechanical properties of the material such as its durability, thermal properties (Ul Haq Bhat et al., 2010) and strength (Hamid et al.,2005; Rokiah et al.,2009 ). Hence, this study was conducted with an intention to expand the utilization of the precious material. The objectives of the study were 1) to utilize oil palm trunk into furniture components by converting them into veneers before they are pressed and molded to desired shapes and forms; 2) to determine suitable pressing pressure, pressing temperature and time to fabricate moulded laminated veneer lumber from OPT with different arrangement of veneer qualities such as superior (S) and inferior (I); 3) to compare the strength in terms of modulus of rupture (MOR) and modulus of elasticity (MOE) by three different types of bending such as flat, type-OV and type-V.

\section{Materials and Method}

\subsection{Materials}

Kin Heng Timber Sdn. Bhd. (KHTSB) Malaysia possessed a complete range of equipments to manufacture MLVOP from primary to the secondary processing. Forest Research Institute Malaysia (FRIM) was given opportunity to use the equipments owned by the company such as rotary machine, conveyer dryer, hot press machine, high frequency machine and mould machine to conduct the research. The oil palm trunks were obtained from Felda Trolak, Perak Darul Ridzuan, Malaysia. MLVOP was made from oil palm veneers which were arranged to perpendicular to grain.

\subsection{Manufacture of moulded laminated veneer lumber}

The MLVOP was fabricated using hot press or high frequency technology. The products can be created in various shapes and forms depending on mould design. A research was carried out by Hamid et al (2005), indicated that veneer recovery from 9 feet-length of OPT was approximately $45 \%-50 \%$. The veneer recovery increased more than 55\%, when the length of the trunk was decreased for producing as furniture components. The veneer recovery determination procedures are presented in Figure 1. The increase of recovery rate was due to the two types of peeler machines namely peeler with and without chuck (spindles peeler machine). The remainder which is the center part of the OPT is normally $100 \mathrm{~mm}$ in diameter and considered as waste. The processes of manufacturing MLVOP are presented in Figure 2. The veneers were cut into $2.0 \mathrm{ft} x 4.0 \mathrm{ft}$ and were dried approximately 6 to 9\% MC. The liquid adhesives used in this study were phenol formaldehyde (PF) liquid adhesive resin that was formulated for weather-bond plywood (WBP) and urea formaldehyde (UF) liquid adhesive resin that was formulated for moisture-resistant plywood. The liquid adhesives were supplied by the Malayan Adhesive and Chemicals Sdn. Bhd. Both adhesives were applied onto the veneer surfaces using a glue spreader. The MLVOP was then hot-pressed with selected pressures of $1500 \mathrm{psi}, 2000 \mathrm{psi}$ and $2500 \mathrm{psi}$. Time and temperature for both adhesives were $20 \mathrm{~min}$ and $110{ }^{\circ} \mathrm{C}$ respectively. The moulding process was done during the hot-pressing. After hot pressed, the fabricated composites (Figure 3) were removed from the hot press machine and were left cooled by the surrounding, before they were then conditioned in a conditioning room at a temperature of $20 \pm 2^{\circ} \mathrm{C}$ and $65 \pm 5 \%$ relative humidity (RH).

\subsection{Mechanical testing}

The finished boards were trimmed into specified width approximately $400 \mathrm{~mm}$ and the length was preserved. The boards were later cut for bending tests (flat, type-v and type-ov) which 30 replicates were utilized for each test in accordance with BS EN 310:1993 (Anon, 1993). The laminated veneers were cut into a dimension of 290 $\mathrm{mm}(\mathrm{l}) \times 50 \mathrm{~mm}(\mathrm{w}) \times 12 \pm 2 \mathrm{~mm}(\mathrm{t})$

\section{Results and Discussions}

Flat bending test results of different veneer arrangements and pressures which were bonded with UF and PF adhesives are exhibited in Table 1 and Table 2. Type-OV bending test results are recorded under Table 3 and 4. Type- $\mathrm{V}$ bending strength results are shown in Table 5 and 6.

\subsection{Flat Bending Test}

\subsubsection{Modulus of Rupture (MOR)}

All the tested samples bonded with UF resin were found to surpass the MOR standard requirement value, however reverse results were observed for samples bonded with PF resin. Veneer arrangements have given insignificant difference to MOR for the boards bonded with UF resin. Modulus of rupture was also found to be affected by different hot pressing pressures. Insignificant difference on MOR values was recorded for pressures of 1500 psi and 2000 psi. The samples bonded using PF resin were significantly difference between veneer arrangement and pressure level for both MOR and MOE of flat bending strength. By comparing the results, it can be seen that samples bonded with UF showed higher mean MOR values compared to samples bonded with $\mathrm{PF}$ resin with in relationship with veneer arrangements and pressing pressures. Urea formaldehyde-bonded samples which were pressed at 1500psi and arranged with different veneer arrangements (S-I, S100\% and surface superior and core inferior (SS-CI)) exhibited superior mean MOR values i.e. $18.88 \mathrm{MPa}, 30.44 \mathrm{MPa}$ and 23.57 MPa respectively compared to PF-bonded samples. Under the same pressing pressure and veneer arrangements, the mean MOR values for PF-treated samples were 13.55 MPa, 28.01 MPa and 11.65 MPa respectively. As for the pressing pressure of $2000 \mathrm{psi}$, the results of UF-treated samples were still superior to 
PF-treated samples, except for samples with S100\% veneer arrangement, where, the value was $18.66 \mathrm{MPa}$, compared to the UF-treated samples under the same veneer arrangement which exhibited higher mean value i.e 32.33 MPa. Pressing pressure of $2500 \mathrm{psi}$ showed similar MOR result pattern which was obtained under $1000 \mathrm{psi}$ pressing pressure. The mean MOR values for UF-resin treated samples (S-I, S100\%, SS-CI arrangements) were 29.99 MPa, 28.26 MPa and 28.83 MPa respectively. As for the PF-treated samples, the values were $19.56 \mathrm{MPa}$, $20.94 \mathrm{MPa}$ and $12.43 \mathrm{MPa}$ respectively.

\subsubsection{Modulus of elasticity}

Varieties of results were presented for means MOE values of the flat MLVOP samples. The pressing pressures were found to give significant impact to the MOE values. The standard requirement value for MOE is $2000 \mathrm{MPa}$. In comparison with the standard requirement value, it seems that samples which were treated with UF resin surpassed the value except the one that the veneers were arranged with S-I arrangement (1643.86 MPa). Veneer arrangements gave significant difference to MOE of samples bonded with UF resin. For samples bonded with PF resin, under each pressing pressure, the highest MOE values were obtained when the veneers were arranged with S100\% arrangement. Samples bonded with UF resins were also showing the highest values with that arrangement type, except for those who were pressed with the pressing pressure of $2500 \mathrm{psi}$

\subsection{Type-OV Bending Test}

The MOR and MOE values for samples bent with type-OV bending test were found lower than flat bending-tested samples

\subsubsection{Modulus of Rupture (MOR)}

The MOR means values of MLVOP bonded with UF resin were higher than those bonded with PF resin under the all three pressing pressures and veneer arrangements. Veneer arrangement has given insignificant different on the MOR of the samples bonded with UF resin, however pressing pressure was otherwise. The MOR means values for samples bonded with UF resin with respect to the veneer arrangements ( S-I, S100\% and SS-CI) under 1500 psi pressure were $12.36 \mathrm{MPa}, 9.74 \mathrm{MPa}$ and $12.10 \mathrm{MPa}$ respectively. Values for MOR under $2000 \mathrm{psi}$ were 14.98 MPa, 17.91 MPa and 18.87 MPa respectively. Meanwhile, for $2500 \mathrm{psi}$, the means values were $20.54 \mathrm{MPa}$, $21.79 \mathrm{MPa}$ and 16.95 MPa respectively. Inferior MOR means values (under 1500 psi pressure) for samples bonded with PF were 7.37 MPa, 6.56 MPa and 8.94 MPa respectively. When the samples pressed with $2000 \mathrm{psi}$, the MOR values became slightly lower, 7.77 MPa, 6.40 MPa and 8.68 MPa respectively. The means values were 13.17 MPa, 9.51 MPa and 12.15 MPa respectively as the pressing pressure was $2500 \mathrm{psi}$.

\subsubsection{Modulus of Elasticity (MOE)}

Based on the data analysis, the veneer arrangements gave significant effect to the MOE means values for MLVOP samples bonded with UF or PF resin. It seems that the MOE means values for the samples bonded with PF were inferior to those bonded with UF resin for pressing pressures as well as veneer arrangements except those arranged with S-1 then pressed with 1500psi and 2500psi. Most of the highest mean MOE values came from samples fabricated with S100\% veneer arrangement for both resins except when they were pressed with 2000psi and bonded with PF resin. The means values were 828.45 MPa (1500psi-UF), $1386.40 \mathrm{MPa}$ (2000 psi-UF), 1141.47 MPa (2500 psi-UF), 764.22 MPa (1500psi-PF) and 828.75 MPa (2500psi-PF). This showed that the $\mathrm{S} 100 \%$ arrangement was the most effective to increase the elasticity of the MLVOP samples.

\subsection{Type-V Bending Test}

Like type-OV-bending samples, the means MOR and MOE values of the type-V-bending samples were also found inferior to the flat-bending samples.

\subsubsection{Modulus of Rupture (MOR)}

Table 5 reveals the bending strength of UF-bonded MLVOP with different veneer arrangements and pressing pressures. All the three pressing pressures gave significant effect to the MOR values. Veneer arrangements did not influenced the values except for laminated veneers arranged with $\mathrm{S} 100 \%$ veneer arrangement. The laminated veneers arranged with S100\% recorded the highest MOR mean values when they were pressed with 2000 and 2500 psi. The mean values were $23.04 \mathrm{MPa}$ and $37.05 \mathrm{MPa}$ respectively. Laminated veneers arranged with SS-CI veneer arrangement exhibited the highest mean MOR value when pressed with 1000 psi, where the value was $14.48 \mathrm{MPa}$. Different results were presented by laminated veneers bind with PF resin. The veneer arrangements and pressing pressures gave insignificant effects to the MOR values, except for 2500psi pressing pressure. In comparison with resin type, clearly samples bind with UF resin were having higher MOR values compared to the samples bind with PF resin.

\subsubsection{Modulus of Elasticity (MOE)}

The result patterns were similar to MOR. The veneer arrangement and pressing pressures affected the MOE values. Urea formaldehyde-bonded samples performed better than PF-bonded samples. For UF-bonded samples, those arranged with $\mathrm{S} 100 \%$ recorded the highest means MOE values under all the three pressing pressures (1500 psi, $2000 \mathrm{psi}$ and $2500 \mathrm{psi}$ ). Respectively, the values were 1090.91 MPa, 1704.29 MPa and 37.05 MPa. These indicate that the best veneer arrangement and resin type to fabricate type V MLVOP with good elasticity are 
S100\% and PF resin respectively.

\section{Conclusions}

The method of segregating OPT veneers into two categories, namely, Superior (S) and Inferior (I) was identified as important parameters in producing MLVOP. Different arrangements of veneer quality, pressing pressure and temperature have also affected the strength of the fabricated MLVOP. Most MLVOP samples bent with flat-bending test possessed superior results in comparison with samples bent with type- $\mathrm{V}$ and type-OV bending tests. In conclusion the oil palm veneer has potential to be made as furniture components, however, further investigation to strengthen the findings should be conducted. It is suggested that the extension of this study is by incorporating the laminated veneer lumber with advance reinforce material such as fiberglass or by mixing the composite with wood veneer, in order to make it more durable and suitable for many services.

\section{References}

Anonymous. (2005a). Nilai Eksport Perabot Meningkat, Mas Kayu, Disember 2005

Anonymous. (2005b). R\&D untuk bahan mentah baru perabot Malaysia, Berita Harian, Berita Ekonomi 15th May 2005

Anonymous. (1993). BS EN 310:1993- Wood-Based Panels: Determination of modulus of elasticity (MOE) in bending and of bending strength

Abdul Hamid, S., Zulkifli, A., Zaihan, J., and Roslan, A. (2005). Physical Performances of Chair and Strength of Furniture Joints Made From Oil Palm and Rubberwood, paper presented at International Symposium on Wood Science and Technology, Pacifico Yokohama, Japan, 27-30 November 2005

Mohd. Zin, J., Mohd. Hanafi, M.T., Zaidon, A., and Mohd. Hamami, S. (1991). Shrinkage properties of palm wood, In. Koh, M.P., Mohd Nor, M.Y., Khoo, K.C. and Nurulhuda, M.N. (Eds.) Seminar Proceeding: Oil Palm Trunk and Other Palmwood Utilization, Oil Palm Fibre Utilisation Committee Malaysia, Kuala Lumpur

U1 Haq Bhat, I., Abdullah, C.K., Abdul Khalil, H.P.S., M. Hakimi, I. and Nurul Fazita, M.R. (2010). Properties Enhancement of resin impregnated agro waste: oil palm trunk lumber, Journal of Reinforced Plastics and Composites 29(22):3301-3308. DOI:10.1177/0731684410372262

Rokiah, H., Siti Noorbaini, S., Othman, S., Lili Hanum, M.Y. (2009). Effects of cold setting adhesives on properties of laminated veneer lumber from oil palm trunks in comparison with rubberwood, European Journal of Wood and Wood Products 69(1):53-61. DOI:10.1007/s00107-009-0405-2

Table 1. Results for Flat Bending Test of MLVOP Bonded Using UF resin

\begin{tabular}{|c|c|c|c|c|c|}
\hline \multicolumn{2}{|c|}{ MOR (S.V. $=18 \mathrm{MPa})$} & \multicolumn{2}{|c|}{ MOE (S.V. = $2000 \mathrm{MPa})$} & \multirow{2}{*}{$\begin{array}{l}\text { Mean } \\
\text { MOR } \\
\text { (Mpa) }\end{array}$} & \multirow{2}{*}{$\begin{array}{l}\text { Mean } \\
\text { MOE } \\
\text { (Mpa) }\end{array}$} \\
\hline $\begin{array}{c}\text { Veneer } \\
\text { Arrangement }\end{array}$ & Pressure & $\begin{array}{c}\text { Veneer } \\
\text { Arrangement }\end{array}$ & Pressure & & \\
\hline S-I ${ }^{a}$ & & S-I ${ }^{a}$ & & 18,88 & 1643,86 \\
\hline $\mathrm{S} 100 \%{ }^{\mathrm{a}}$ & $1500^{\mathrm{a}}$ & $\mathrm{S} 100 \%^{\mathrm{b}}$ & $1500^{\mathrm{a}}$ & 30,44 & 3734,15 \\
\hline $\mathrm{SS}-\mathrm{CI}^{\mathrm{a}}$ & 1500 & $\mathrm{SS}-\mathrm{CI}^{\mathrm{c}}$ & 1500 & 23,57 & 2521,12 \\
\hline S-I ${ }^{a}$ & & S-I ${ }^{a}$ & & 26,35 & 2522,51 \\
\hline $\mathrm{S} 100 \%^{\mathrm{a}}$ & & $\mathrm{S} 100 \%^{\mathrm{b}}$ & & 18,66 & 2728,74 \\
\hline $\mathrm{SS}-\mathrm{CI}{ }^{\mathrm{a}} \mathrm{I}$ & 2000 & $\mathrm{SS}-\mathrm{CI}{ }^{\mathrm{c}}$ & $2000^{\circ}-a-a-x$ & 26,07 & 2433,71 \\
\hline S-I ${ }^{a}$ & & S-I ${ }^{a}$ & & 29,99 & 2526,95 \\
\hline $\mathrm{S} 100 \%{ }^{\mathrm{a}}$ & $2500^{\mathrm{b}}$ & $\mathrm{S} 100 \%^{\mathrm{b}}$ & $2500^{\mathrm{a}}$ & 28,26 & 2196,65 \\
\hline SS-CI & & & & 28,83 & 2572,08 \\
\hline
\end{tabular}

Means with the same letter are not significantly different at $\alpha=0.05$ by Duncan

- Waller-Duncan Test; S.V. =standard value 
Table 2. Results of Flat Bending Test of MLVOP Bonded Using PF Resin

\begin{tabular}{|c|c|c|c|c|c|}
\hline \multicolumn{2}{|c|}{ MOR (S.V. $=18 \mathrm{MPa})$} & \multicolumn{2}{|c|}{ MOE (S.V. $=2000 \mathrm{MPa})$} & \multirow{2}{*}{$\begin{array}{l}\text { Mean } \\
\text { MOR } \\
\text { (Mpa) }\end{array}$} & \multirow{2}{*}{$\begin{array}{l}\text { Mean } \\
\text { MOE } \\
(\mathrm{Mpa})\end{array}$} \\
\hline $\begin{array}{c}\text { Veneer } \\
\text { Arrangement }\end{array}$ & Pressure & $\begin{array}{c}\text { Veneer } \\
\text { Arrangement }\end{array}$ & Pressure & & \\
\hline $\mathrm{S}-\mathrm{I}^{\mathrm{a}}$ & & $\mathrm{S}-\mathrm{I}^{\mathrm{a}}$ & & 13,55 & 1644,85 \\
\hline $\mathrm{S} 100 \%{ }^{\mathrm{b}}$ & $1500^{\mathrm{a}}$ & $\mathrm{S} 100 \%^{\mathrm{b}}$ & $1500^{\mathrm{a}}$ & 28,01 & 3438,46 \\
\hline SS-CI ${ }^{c}$ & $1500^{\circ}$ & $\mathrm{SS}-\mathrm{CI}^{\mathrm{c}}$ & $1500^{\circ}$ & 11,65 & 1389,35 \\
\hline S-I ${ }^{a}$ & & S-I ${ }^{a}$ & & 22,51 & 2054,54 \\
\hline $\mathrm{S} 100 \%^{\mathrm{b}}$ & & $\mathrm{S} 100 \%{ }^{\mathrm{b}}$ & & 32,33 & 3995,10 \\
\hline SS-CI ${ }^{c}$ & $2000^{\circ}$ & $\mathrm{SS}-\mathrm{CI}^{\mathrm{c}}$ & $2000^{\circ}$ & 19,04 & 2316,34 \\
\hline S-I ${ }^{a}$ & & S-I ${ }^{a}$ & & 19,56 & 1853,67 \\
\hline $\mathrm{S} 100 \%{ }^{\mathrm{b}}$ & $2500^{\mathrm{a}}$ & $\mathrm{S} 100 \%{ }^{\mathrm{b}}$ & $2500^{\mathrm{c}}$ & 20,94 & 2412,98 \\
\hline $\mathrm{SS}-\mathrm{CI}^{\mathrm{c}}$ & $2500^{\circ}$ & $\mathrm{SS}-\mathrm{CI}{ }^{\mathrm{c}}$ & 2500 & 12,43 & 1201,31 \\
\hline
\end{tabular}

Means with the same letter are not significantly different at $\alpha=0.05$ by Duncan Waller-Duncan Test; S.V.= standard value

Table 3. Results for Type-OV Bending Test of MLVOP Bonded Using UF Resin

\begin{tabular}{|c|c|c|c|c|c|}
\hline \multicolumn{2}{|c|}{$\begin{array}{l}\text { MOR (values to compare } \\
\text { with flat-bending samples) }\end{array}$} & \multicolumn{2}{|c|}{$\begin{array}{l}\text { MOE (values to compare } \\
\text { with flat-bending samples) }\end{array}$} & \multirow{2}{*}{$\begin{array}{l}\text { Mean } \\
\text { MOR } \\
\text { (Mpa) }\end{array}$} & \multirow{2}{*}{$\begin{array}{l}\text { Mean } \\
\text { MOE } \\
\text { (Mpa) }\end{array}$} \\
\hline $\begin{array}{c}\text { Veneer } \\
\text { Arrangement }\end{array}$ & Pressure & $\begin{array}{c}\text { Veneer } \\
\text { Arrangement }\end{array}$ & Pressure & & \\
\hline $\begin{array}{l}\text { S-I }{ }^{\text {a }}{ }^{\text {a }} \\
\text { S100\% }{ }^{\text {a }} \\
\text { SS-CI }\end{array}$ & $1500^{\mathrm{a}}$ & $\begin{array}{l}\text { S-I }{ }^{a}{ }^{a} \\
\text { S100\% }{ }^{b} \\
\text { SS-CI }^{c}\end{array}$ & $1500^{a}$ & $\begin{array}{c}12,36 \\
9,74 \\
12,10\end{array}$ & $\begin{array}{l}465,98 \\
828,45 \\
618,44\end{array}$ \\
\hline $\begin{array}{l}\text { S-I }{ }^{a} \\
\text { S100\% }{ }^{a} \\
\text { SS-CI }^{a}\end{array}$ & $2000^{b}$ & $\begin{array}{l}\text { S-I }{ }^{a} \\
\text { S100\% }{ }^{b} \\
\text { SS-CI }^{c}\end{array}$ & $2000^{b}$ & $\begin{array}{l}14,98 \\
17,91 \\
18,87\end{array}$ & $\begin{array}{c}724,59 \\
1386,40 \\
1093,43\end{array}$ \\
\hline $\begin{array}{l}\text { S-I }{ }^{\mathrm{a}} \\
\text { S } 100 \%^{\text {a }} \\
\text { SS-CI }\end{array}$ & $2500^{c}$ & $\begin{array}{l}\text { S-I }{ }^{\mathrm{a}} \\
\mathrm{S} 100 \%{ }^{\mathrm{b}} \\
\mathrm{SS}^{\mathrm{b}}-\mathrm{CI}^{\mathrm{c}}\end{array}$ & $2500^{a}$ & $\begin{array}{l}20,54 \\
21,79 \\
16,95\end{array}$ & $\begin{array}{c}548,61 \\
1141,47 \\
612,60\end{array}$ \\
\hline
\end{tabular}

Means with the same letter are not significantly different at $\alpha=0.05$ by Duncan Waller-Duncan Test

Table 4. Results for Type-OV Bending Test of MLVOP Bonded with PF Resin

\begin{tabular}{|c|c|c|c|c|c|}
\hline \multicolumn{2}{|c|}{ MOR } & \multicolumn{2}{|c|}{ MOE } & Mean & Mean \\
\hline $\begin{array}{c}\text { Veneer } \\
\text { Arrangement }\end{array}$ & Pressure & $\begin{array}{c}\text { Veneer } \\
\text { Arrangement }\end{array}$ & Pressure & $\begin{array}{l}\text { MOR } \\
(\mathrm{Mpa})\end{array}$ & $\begin{array}{l}\text { MOE } \\
\text { (Mpa) }\end{array}$ \\
\hline S-I ${ }^{a}$ & & S-I ${ }^{a}$ & & 7,37 & 535,64 \\
\hline $\mathrm{S} 100 \%^{\mathrm{b}}$ & $1500^{a}$ & $\mathrm{~S} 100 \%{ }^{b}$ & $1500^{a}$ & 6,56 & 764,22 \\
\hline $\mathrm{SS}-\mathrm{CI}^{\mathrm{a}}$ & & $\mathrm{SS}-\mathrm{CI}{ }^{\mathrm{c}}$ & & 8,94 & 497,65 \\
\hline S-I ${ }^{a}$ & & S-I ${ }^{a}$ & & 7,77 & 506,38 \\
\hline $\mathrm{S} 100 \%^{\mathrm{b}}$ & $2000^{\mathrm{a}}$ & $\mathrm{S} 100 \%^{\mathrm{b}}$ & $2000^{\mathrm{a}}$ & 6,40 & 459,64 \\
\hline SS-CI ${ }^{\text {a }}$ & & $\mathrm{SS}-\mathrm{CI}^{\mathrm{c}}$ & & 8,68 & 658,66 \\
\hline S-I ${ }^{\mathrm{a}}$ & & S-I ${ }^{a}$ & & 13,17 & 590,55 \\
\hline $\mathrm{S} 100 \%{ }^{\mathrm{b}}$ & $2500^{\mathrm{b}}$ & $\mathrm{S} 100 \%{ }^{b}$ & $2500^{a}$ & 9,51 & 828,75 \\
\hline $\mathrm{SS}-\mathrm{CI} \mathrm{a}^{\mathrm{a}}$ & & $\mathrm{SS}-\mathrm{CI}^{\mathrm{c}}$ & & 12,15 & 595,15 \\
\hline
\end{tabular}

Means with the same letter are not significantly different at $\alpha=0.05$ by Duncan Waller-Duncan Test 
Table 5. Results for Type-V Bending Test of MLVOP Bonded using UF Resin

\begin{tabular}{|c|c|c|c|c|c|}
\hline \multicolumn{2}{|c|}{$\begin{array}{c}\text { MOR (values to compare } \\
\text { with the flat-bending } \\
\text { samples) }\end{array}$} & \multicolumn{2}{|c|}{$\begin{array}{l}\text { MOE (values to compare } \\
\text { with flat-bending samples) }\end{array}$} & \multirow[t]{2}{*}{$\begin{array}{l}\text { Mean } \\
\text { MOR } \\
\text { (Mpa) }\end{array}$} & \multirow[t]{2}{*}{$\begin{array}{l}\text { Mean } \\
\text { MOE } \\
\text { (Mpa) }\end{array}$} \\
\hline $\begin{array}{c}\text { Veneer } \\
\text { Arrangement }\end{array}$ & Pressure & $\begin{array}{c}\text { Veneer } \\
\text { Arrangement }\end{array}$ & Pressure & & \\
\hline S-I ${ }^{\text {a }}$ & & S-I ${ }^{a}$ & & 10,97 & 374,46 \\
\hline $\mathrm{S} 100 \%^{\mathrm{b}}$ & $1500^{\mathrm{a}}$ & $\mathrm{S} 100 \%{ }^{\mathrm{b}}$ & $1500^{\mathrm{a}}$ & 13,45 & 1090,91 \\
\hline $\mathrm{SS}-\mathrm{CI}^{\mathrm{a}}$ & & SS-CI ${ }^{b}$ & & 14,48 & 740,09 \\
\hline S-I ${ }^{a}$ & & S-I ${ }^{\text {a }}$ & & 14,19 & 740,51 \\
\hline $\mathrm{S} 100 \%{ }^{b}$ & $2000^{b}$ & $\mathrm{~S} 100 \%^{\mathrm{b}}$ & $2000^{b}$ & 23,04 & 1704,29 \\
\hline $\mathrm{SS}-\mathrm{CI}{ }^{\mathrm{a}}$ & & SS-CI ${ }^{b}$ & & 22,73 & 1078,85 \\
\hline S-I ${ }^{\text {a }}$ & & S-I ${ }^{a}$ & & 25,76 & 804,07 \\
\hline $\mathrm{S} 100 \%^{\mathrm{b}}$ & $2500^{c}$ & $\mathrm{~S} 100 \%^{\mathrm{b}}$ & $2500^{c}$ & 37,05 & 37,05 \\
\hline SS-CI ${ }^{a}$ & & SS-CI ${ }^{b}$ & & 22,94 & 742,63 \\
\hline
\end{tabular}

Waller-Duncan Test

Table 6. Results for Type-V Bending Test of MLVOP Bonded Using PF Resin

\begin{tabular}{|c|c|c|c|c|c|}
\hline \multicolumn{2}{|c|}{$\begin{array}{l}\text { MOR (values to compare } \\
\text { with flat-bending samples) }\end{array}$} & \multicolumn{2}{|c|}{$\begin{array}{l}\text { MOE (values to compare } \\
\text { with flat-bending samples) }\end{array}$} & \multirow{2}{*}{$\begin{array}{l}\text { Mean } \\
\text { MOR } \\
\text { (Mpa) }\end{array}$} & \multirow{2}{*}{$\begin{array}{l}\text { Mean } \\
\text { MOE } \\
\text { (Mpa) }\end{array}$} \\
\hline $\begin{array}{c}\text { Veneer } \\
\text { Arrangement }\end{array}$ & Pressure & $\begin{array}{c}\text { Veneer } \\
\text { Arrangement }\end{array}$ & Pressure & & \\
\hline S-I ${ }^{a}$ & & S-I ${ }^{a}$ & & 8,67 & 745,05 \\
\hline $\mathrm{S} 100 \%{ }^{\mathrm{a}}$ & $1500^{a}$ & $\mathrm{~S} 100 \%^{\mathrm{a}}$ & $1500^{\mathrm{a}}$ & 7,91 & 677,00 \\
\hline SS-CI a & & SS-CI ${ }^{\text {a }}$ & & 9,17 & 426,98 \\
\hline S-I ${ }^{a}$ & & S-I ${ }^{a}$ & & 11,93 & 623,21 \\
\hline $\mathrm{S} 100 \%^{\mathrm{a}}$ & $2000^{a}$ & $\mathrm{~S} 100 \%{ }^{\mathrm{a}}$ & $2000^{a}$ & 8,72 & 659,38 \\
\hline $\mathrm{SS}-\mathrm{CI}^{\mathrm{a}}$ & & SS-CI ${ }^{a}$ & & 9,82 & 760,53 \\
\hline S-I ${ }^{a}$ & & S-I ${ }^{a}$ & & 14,61 & 674,04 \\
\hline $\mathrm{S} 100 \%^{\mathrm{a}}$ & $2500^{b}$ & $\mathrm{~S} 100 \%^{\mathrm{a}}$ & $2500^{a}$ & $\begin{array}{l}14,01 \\
10,15\end{array}$ & 885,60 \\
\hline $\mathrm{SS}-\mathrm{CI}^{\mathrm{a}}$ & & SS-CI ${ }^{\text {a }}$ & & $\begin{array}{l}10,15 \\
14,22\end{array}$ & $\begin{array}{l}805,00 \\
806,77\end{array}$ \\
\hline
\end{tabular}

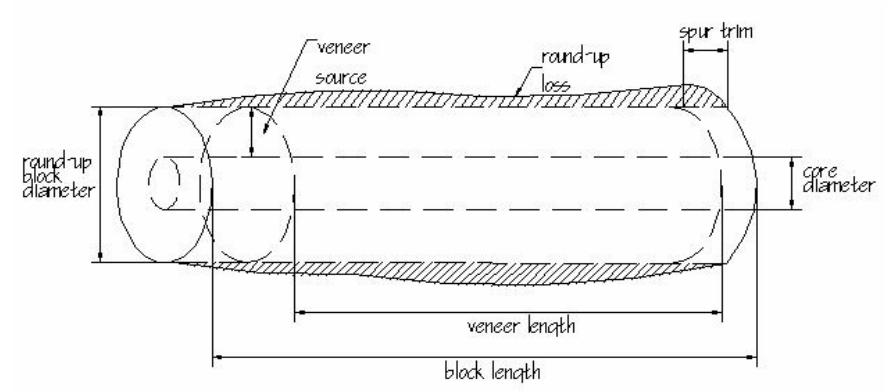

Figure 1. Veneer Recovery Determination 


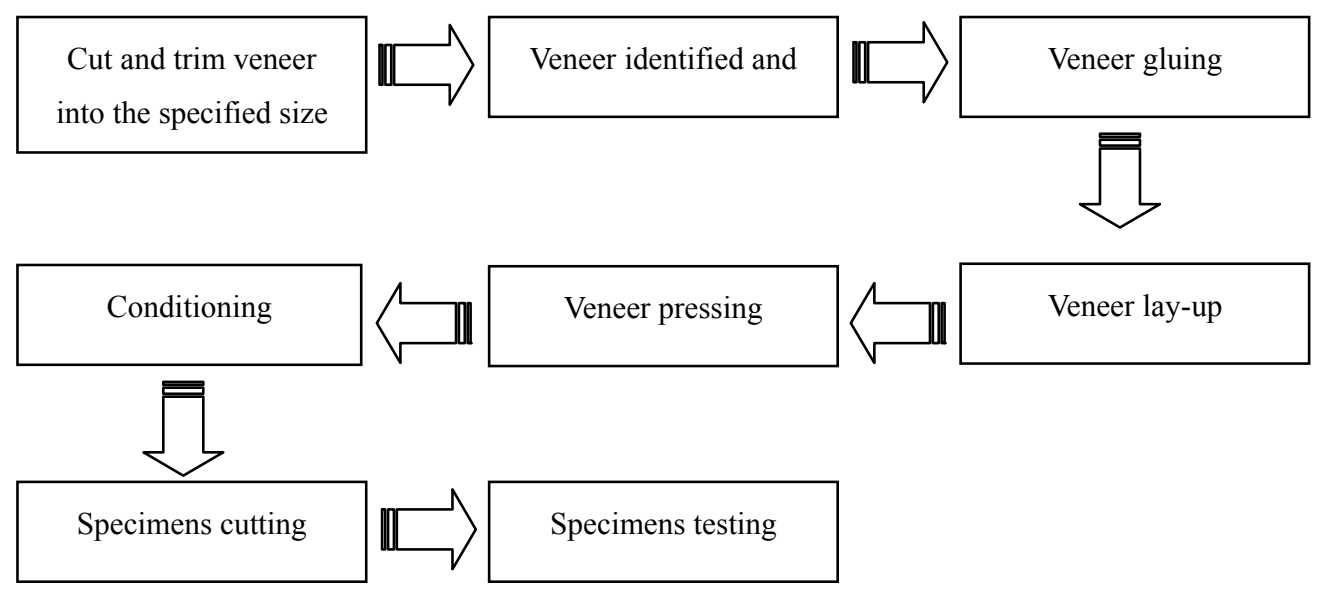

Figure 2. Manufacturing Process of MLVOP

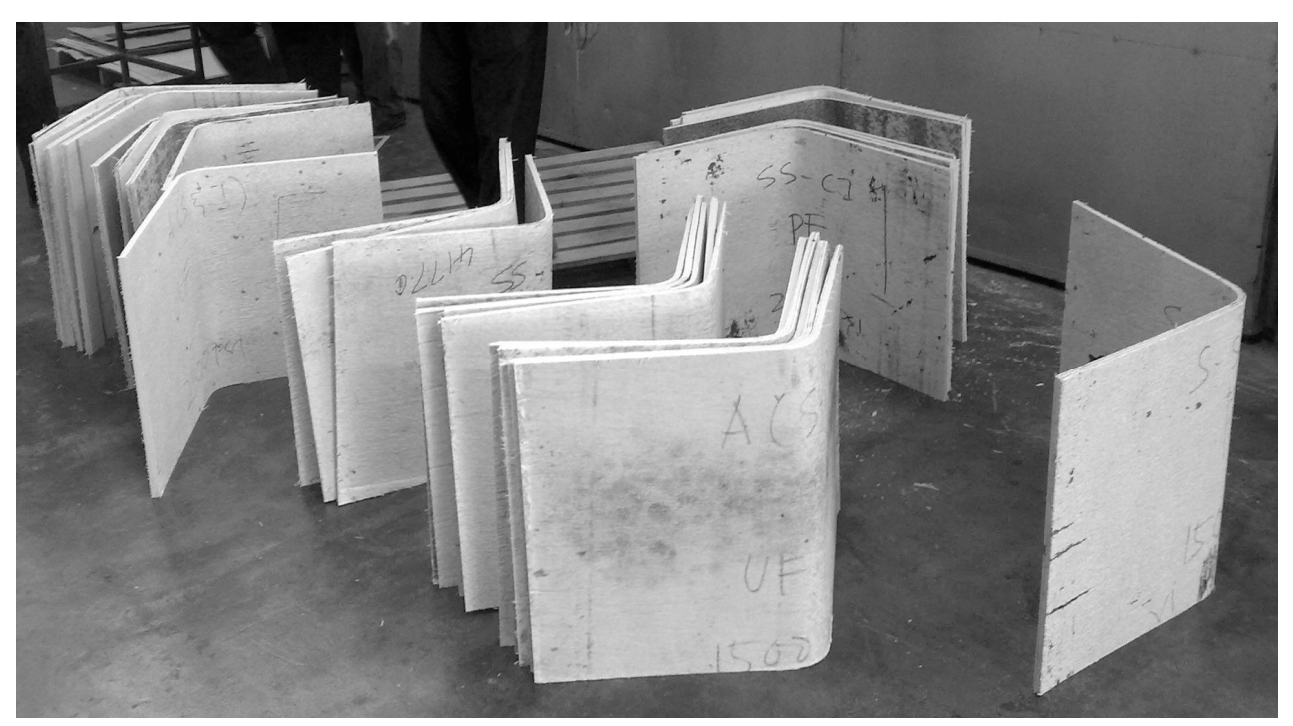

Figure 3. The fabricated MLVOPs 


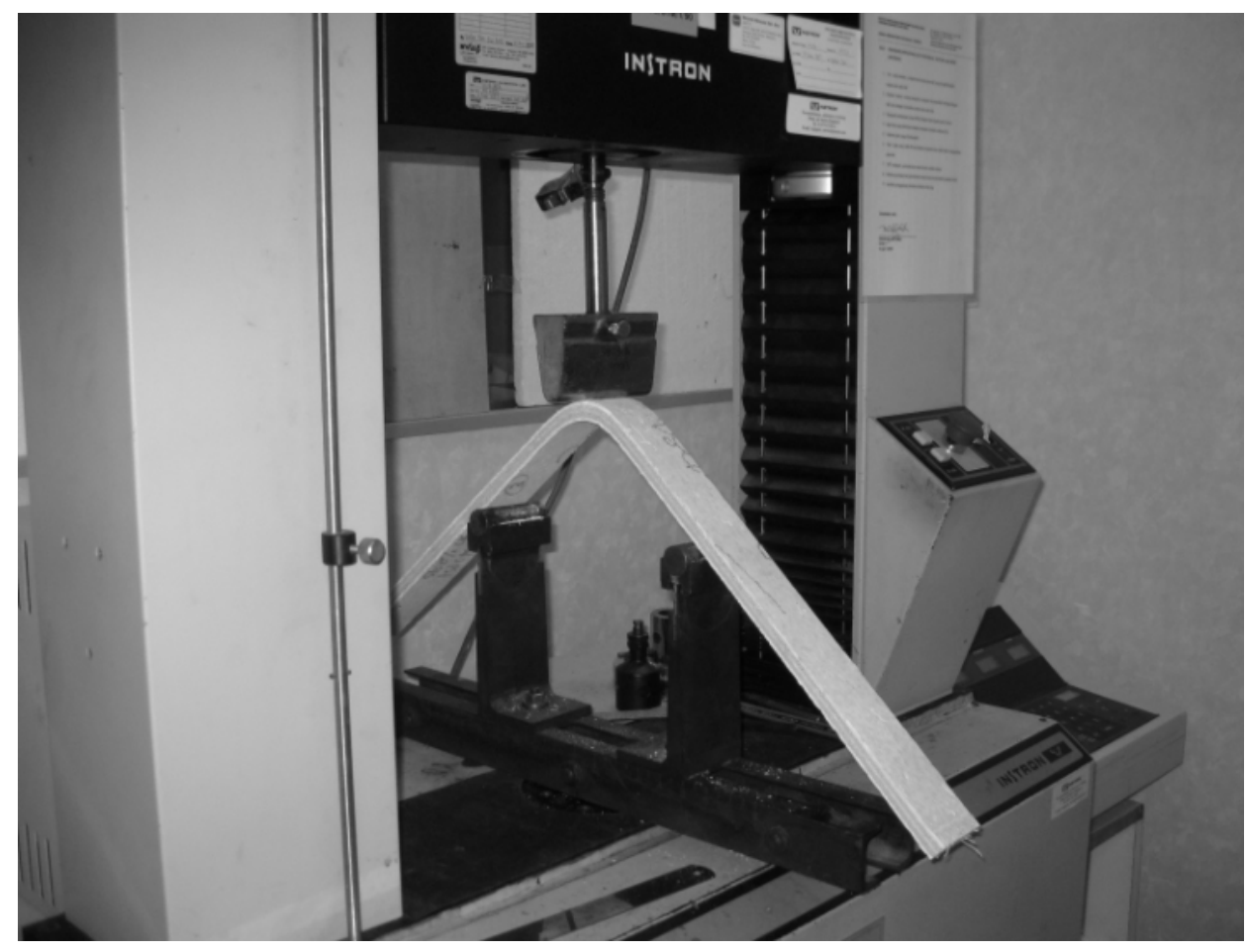

Figure 4. Type-OV Bending Test

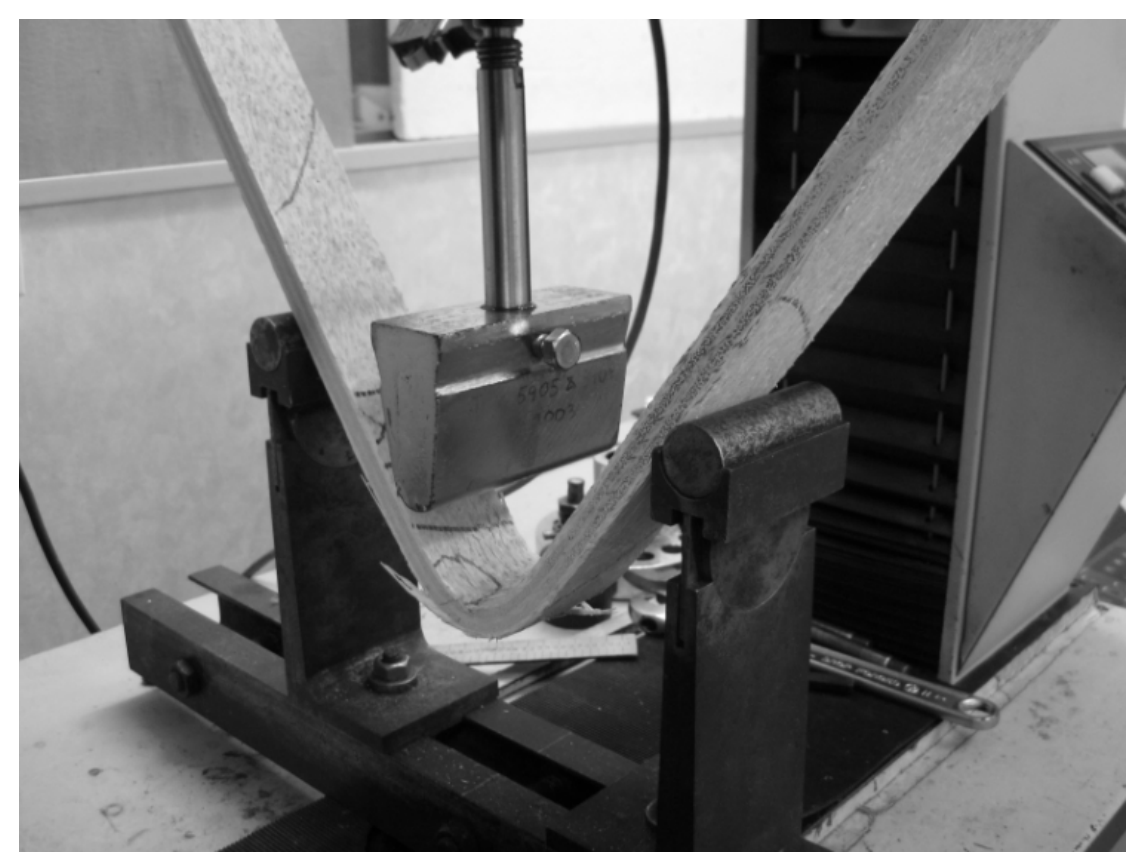

Figure 5. Type-V Bending Test 